\title{
Description and quantification of developmental abnormalities in a natural Sepioteuthis australis spawning population (Mollusca: Cephalopoda)
}

\author{
F. C. Gowland ${ }^{1, *}$, N. A. Moltschaniwskyj ${ }^{2}$, M. A. Steer ${ }^{2,3}$ \\ ${ }^{1}$ Department of Zoology, University of Aberdeen, Tillydrone Avenue, Aberdeen AB24 2TZ, Scotland, UK \\ ${ }^{2}$ School of Aquaculture, and ${ }^{3}$ Marine Research Laboratories, Tasmanian Aquaculture and Fisheries Institute, \\ University of Tasmania, Locked Bag 1-370, Launceston, Tasmania 7250, Australia
}

\begin{abstract}
Eggs of the southern calamary Sepioteuthis australis were sampled from spawning sites off eastern Tasmania, Australia, during an austral spring/summer spawning season. At fortnightly intervals, 3 unfouled and 3 biofouled egg strands were sampled from 6 to 23 distinct egg masses $\left(\mathrm{N}_{\text {eggs }}=2649\right.$ ). Highly significant variation was noted between sample dates in the frequency of unfertilised eggs, developmental abnormalities and egg mortalities. Unfertilised eggs were only found during late October and early November and represented a mean $2.12 \pm 1.25 \%$ SE and $0.58 \pm 0.58 \%$ SE eggs per strand respectively. Frequency of abnormality varied significantly between sample dates and ranged from $8.35 \pm 1.86 \%$ SE eggs per strand in late November to $0.92 \pm 0.41 \%$ SE in late December. Abnormalities were arbitrarily categorised as defects in external yolk sac morphology, reduced embryonic size, mantle deformities, eye deformities and arm deformities. Defects in external yolk sac morphology were found throughout the spawning season and accounted for $46.3 \%$ of all abnormalities. Incidence of mortality varied significantly between sample dates and ranged from $1.40 \pm 0.68 \%$ SE per strand in late October to $11.61 \pm 3.23 \%$ SE in early January. Highly significant correlation was noted between incidence of developmental abnormality and within-strand egg position. Biofouled egg strands were characterised by comparatively low incidences of unfertilised and dead eggs. The influences of environment, egg position and biofouling upon embryonic development in $S$. australis are discussed.
\end{abstract}

KEY WORDS: Squid $\cdot$ Embryos $\cdot$ Abnormality $\cdot$ Mortality $\cdot$ Temperature $\cdot$ Egg position $\cdot$ Biofouling Resale or republication not permitted without written consent of the publisher

\section{INTRODUCTION}

Developmental abnormalities have been identified within the eggs and embryos of many marine taxa and are typically associated with unfavourable developmental conditions. Elevated water temperature generates abnormalities in embryos of the echinoid Arachnoides placenta (Chen \& Chen 1992), larvae of the Arctic cod Boreogadus saida (Graham \& Hop 1995) and hatchlings of the tilapia Oreochromis mossambicus (Wang \& Tsai 2000). Increased salinity promotes abnormalities in megalopae of the crab Rhithropanopeus harrisii (Gonçalves et al. 1995), and exposure to UV-B radiation induces embryonic abnormalities in the green

*Email: f.gowland@abdn.ac.uk sea urchin Strongylocentrotus droebachiensis (Adams \& Shick 2001). In situ sampling of amphipod populations in the Baltic Sea indicates rates of embryonic abnormality between 1.5 and $4.9 \%$ (Monoporeia affinis; Sundelin \& Eriksson 1998). Similar sampling of copepod nauplii off Japan suggests an incidence of abnormality between 20 and $40 \%$ (Pseudocalanus newmani; Ban et al. 2000). The extent of variation between and within these estimates may reflect class, species, population and/or season specificity in frequency of embryonic abnormality. Distinct seasonality has been noted in incidence of abnormal eggs, embryos and veligers within gastropod populations; abnormalities are most prevalent within broods developing outside the main reproductive season (Littorina saxatilis: Sokolova 1995; L. neglecta: Johnson et al. 2000). Irrespective of cause, 
variation in the incidence of embryonic abnormality may potentially influence rates of recruitment with flow-on effects to population size and structure. For short-lived species, such variation in successful production of young can have a significant impact. Cephalopod populations are characterised by life-history traits such as short-life spans, semelparity and rapid response to variation in environmental conditions (Rodhouse 2001). Variation in the population size and structure of cephalopod populations may, in part, reflect variation in rates of embryonic abnormality.

Mature loliginid squid typically aggregate in coastal waters to mate and spawn, e.g. Loligo opalescens (McGowan 1954), L. pealei (Arnold 1962), L. vulgaris reynaudii (Sauer et al. 1993), Sepioteuthis lessoniana (Segawa 1987) and S. australis (Moltschaniwskyj \& Pecl unpubl.). Some of the loliginids produce multiple batches of eggs (e.g. L. pealei: Maxwell \& Hanlon 2000), with successive batches being laid over a period of several weeks (e.g. L. vulgaris, L. forbesi: Rocha \& Guerra 1996; L. pealei: Maxwell et al. 1998; L.v. reynaudii: Melo \& Sauer 1999; S. australis, S. lessoniana: Pecl 2001). Individually encapsulated eggs are collectively packaged within gelatinous material to form discrete egg strands (Boletzky 1989). This gelatinous wrapping confers physical protection against mechanical abrasion and chemical protection against microbial infection (e.g. Biggs \& Epel 1991). The spawning behaviour of $S$. australis is consistent with the general loliginid trend. Between October and December each year, large numbers of mature squid aggregate in coastal waters around Tasmania, Australia, to mate and spawn (Moltschaniwskyj \& Pecl unpubl.). Mated females attach multiple egg strands, typically containing between 3 and 9 eggs, onto seagrass or macroalgae holdfasts. Collective deposition of egg strands leads to the formation of discrete egg masses containing $<10$ or $>600$ egg strands (Moltschaniwskyj \& Pecl unpubl.). In common with other cephalopod species, developmental rate in $S$. australis is positively associated with water temperature (Steer et al. 2002). With a life expectancy of 6 to $10 \mathrm{mo}$ (Pecl 2000), the embryonic phase of $S$. australis is equivalent to $20 \%$ of the posthatching life span and represents both a critical formative phase and a significant proportion of the entire life cycle. S. australis embryos undergo direct development to hatch as miniature juveniles of basic adult form. Typical for short-lived species, the success of future squid generations depends entirely upon the ability of present generations to produce viable offspring. Therefore, correct embryonic development represents an important component of this ability.

The present study provides the first in situ assessment of abnormalities within a natural cephalopod population. Incidence of developmental abnormality was quantified within a shallow spawning and commercially exploited
Sepioteuthis australis population off the east coast of Tasmania. Morphological abnormalities have previously been reported in cephalopod eggs reared under laboratory conditions (e.g. Naef 1928, Ranzi 1929, Marthy 1969). Experimental elevation of temperature promotes abnormalities in embryos of the squids Illex illecebrosus (O'Dor et al. 1982), Todarodes pacificus (Sakurai et al. 1996), Loligo vulgaris reynaudii (Oosthuizen et al. 2002b) and L. forbesi (Gowland et al. 2002). Hypoxic conditions at the centre of egg masses induce retardation and abnormal embryonic development in both squid (Loligo spp.: Arnold 1990) and oysters (Crassostrea virginica: Baker \& Mann 1994). Conversely, biofouling of egg capsules has positive effects upon embryonic development in some molluscs and amphibians (e.g. Cohen \& Strathmann 1996, Pinder \& Friet 1994). The specific aims of this study were to identify and quantify developmental abnormalities typically observed in S. australis embryos, and to assess factors affecting incidence of developmental abnormalities, e.g. temperature, withinmass egg position and biofouling.

\section{MATERIALS AND METHODS}

Sepioteuthis australis egg masses were sampled from spawning grounds situated in Great Oyster Bay, eastern Tasmania, Australia ( $\left.42^{\circ} 07^{\prime} 34^{\prime \prime} \mathrm{S}, 148^{\circ} 17^{\prime} 51^{\prime \prime} \mathrm{E}\right)$. At fortnightly intervals between October 2000 and January 2001, SCUBA divers searched 3 discrete areas of the seagrass Amphibolis antarctica for $S$. australis egg masses (Fig. 1). All sample sites were located within $0.5 \mathrm{~km}$ of the shore in 4 to $8 \mathrm{~m}$ of water. Particular emphasis was

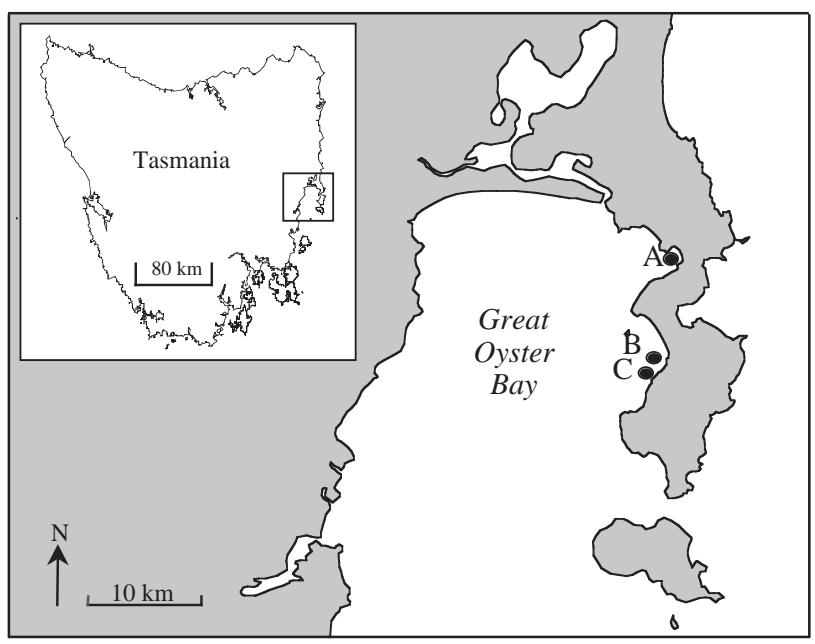

Fig. 1. Sepioteuthis australis. Spawning grounds from this study. Egg strings were collected from discrete areas of the seagrass Amphibolis antarctica $(\mathrm{A}, \mathrm{B}, \mathrm{C})$ at 2 wk intervals between late October 2000 and early January 2001 
placed upon locating egg strands that contained embryos close to hatching. Developmental stage, early or late, was estimated in situ based on egg capsule size and embryo morphology (primarily eye pigmentation). Three unfouled and 3 biofouled egg strands were removed from between 6 and 23 egg masses per sampling trip. Unfouled egg strands were defined as those displaying 0 to $10 \%$ surface coverage by epiphytic algal growth (Fig. 2A). Fouled egg strands were defined as those displaying 50 to $100 \%$ surface coverage (Fig. 2B). All material was bagged in fresh seawater and stored out of direct sunlight prior to dissection.

Egg strands were examined within $8 \mathrm{~h}$ of field collection. Embryos were dissected out and numbered sequentially according to their position within the egg strand (Position 1 = proximal/fixed end of the strand). Individuals were examined under a dissection microscope and allocated a developmental stage according to the criteria described by Steer (unpubl.) for Sepioteuthis australis, which follows that of Segawa (1987) for $S$. lessoniana. Incidence of unfertilised eggs, identified by an opaque appearance and lack of cell division, was calculated per egg strand as a function of sample date (normalised to account for variation in sample site and degree of biofouling). Examination of several thousand embryos generated a clear impression of normal embryonic morphology. Abnormal development was recognised in late stage embryos by an absence of specific organs (e.g. arms or eyes), or by distortions in character shape, size or position relative to the individual (e.g. inversion of the mantle). Abnormalities were arbitrarily allocated into 1 of 5 categories: defects in

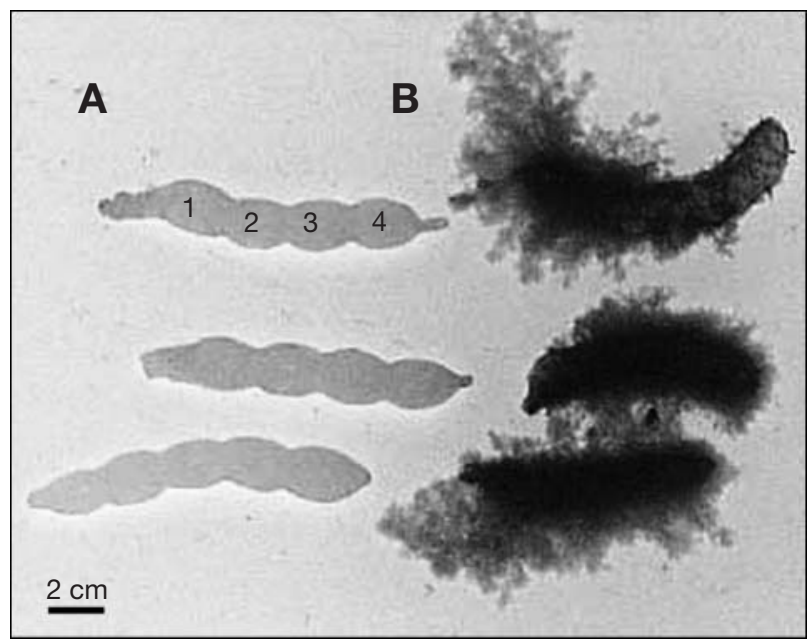

Fig. 2. Sepioteuthis australis. Photograph of field-collected egg strands containing late stage embryos. (A) Unfouled egg strands; (B) biofouled egg strands. Numbers denote withinstrand egg position i.e. 1 = position nearest the proximal/fixed end of the strand external yolk sac morphology, pronounced reduction in embryo size, mantle deformities, eye deformities and arm deformities. Brief visual descriptions of developmental abnormalities were recorded per embryo, and illustrated examples of each category are provided (Fig. 3). Incidence of abnormally developed embryos was calculated per egg strand as a function of sample date (normalised to account for variation in sample site and degree of biofouling). Frequency occurrence of dead embryos, identified by arrested development, was similarly calculated. Dead embryos were scored exclusively as mortalities, i.e. regardless of any developmental abnormality. A total of 84 egg masses yielding 481 egg strands and 2649 embryos were examined during the spawning season.

Information on sea-bottom temperature $\left(\mathrm{SBT}\right.$ in $\left.{ }^{\circ} \mathrm{C}\right)$ was collected to provide background information on ambient conditions during the sampling period. Laboratory rearing of squid eggs (Hanlon 1990) indicates that controlled temperature changes should not exceed $1^{\circ} \mathrm{C} \mathrm{d}^{-1}$ (equivalent to $\Delta 0.04^{\circ} \mathrm{C} \mathrm{h}^{-1}$ ). Hourly SBT was measured in situ during this study in order to provide detailed assessment of natural temperature fluctuations. SBT was measured via a 32K StowAway 'TidbiT' temperature datalogger secured to the seafloor ( $<4 \mathrm{~m}$ deep) at Site A, 1 mo prior to first sampling.

Frequency analyses of data revealed both normal and skewed data distributions. For example, incidence of developmental abnormality per egg strand was skewed on 3 of 6 sample dates (Ryan-Joiner $\mathrm{p}<0.01$; kurtosis 4.68 to 19.87 ; skew 2.19 to 4.11). Data transformation was prohibited by the high frequency of zero values within the data set; therefore, non-parametric techniques were employed. Variation in the relationship between egg position and developmental abnormality was investigated by converting number of abnormalities per position into percentage abnormalities per position on each sample date. Percentage abnormality per $n$th egg position was calculated by analysis of strands containing $\geq n$ eggs. However, as only $15 \%$ of egg strands examined contained $>6$ eggs, results of percentage abnormality at Positions 7, 8 and 9 should be interpreted with caution.

\section{RESULTS}

Highly significant variation was observed between sample dates in frequency of unfertilised eggs (KruskalWallis: $H_{5}=20.62, \mathrm{p}=0.001$ ). Unfertilised eggs were only found during late October and early November and represented a mean $2.12 \pm 1.25 \% \mathrm{SE}$ and $0.58 \pm$ $0.58 \%$ SE of eggs per strand respectively (Fig. 4). Frequency of abnormality per strand differed significantly among sample dates (Kruskal-Wallis: $H_{5}=28.48, \mathrm{p}<$ 
$0.001)$, with mean incidence ranging between $8.35 \pm$ $1.86 \% \mathrm{SE}$ and $0.92 \pm 0.41 \%$ SE eggs per strand in late November and late December respectively (Fig. 4). Defects in external yolk sac morphology accounted for $46.3 \%$ of all abnormalities (Table 1) and were characterised by fissures within the yolk, pinching of the yolk, or convolution of the yolk (Fig. 3A). These defects indi- cated abnormal development that would not progress beyond gastrulation (Stage 12). Pronounced reduction of embryonic size, recognised on the basis of comparison with embryos of equivalent developmental stage, accounted for $27.8 \%$ of abnormalities (Table 1). Reductions in embryonic size were often accompanied by a larger than normal yolk sac (Fig. 3B), or by separation

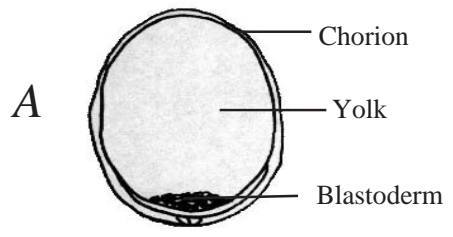

Normal morphology

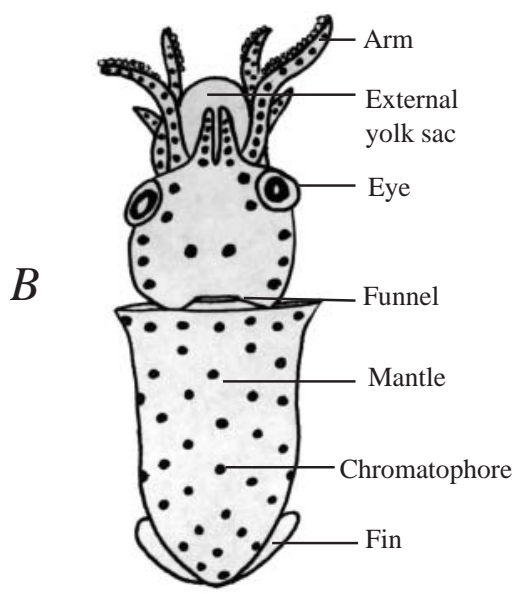

Normal morphology (ventral / dorsal)

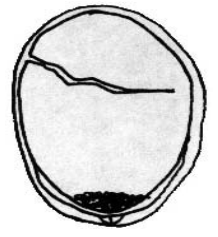

Fissured yolk

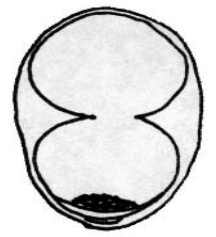

Pinched yolk

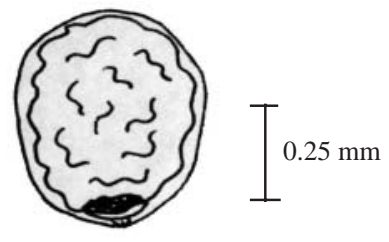

Convoluted yolk

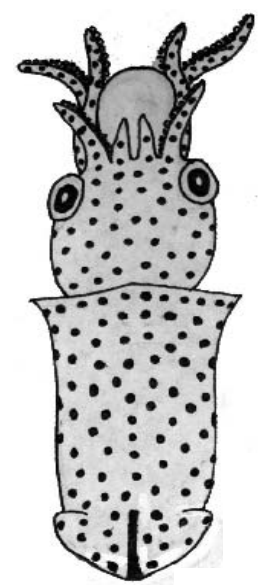

Reduced embryonic size (dorsal)

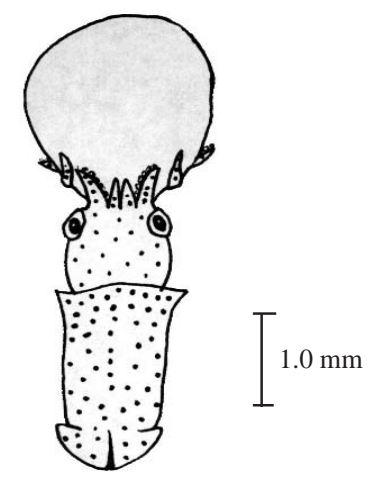

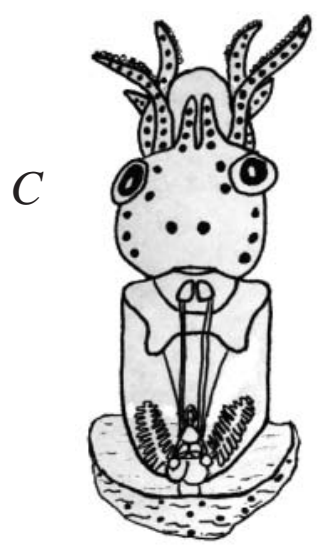

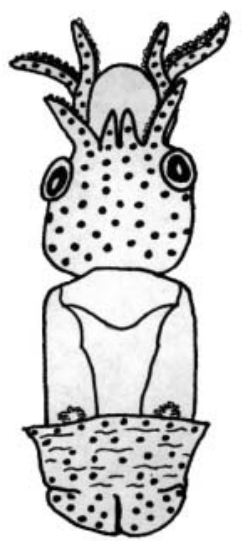

Mantle detached (ventral / dorsal)

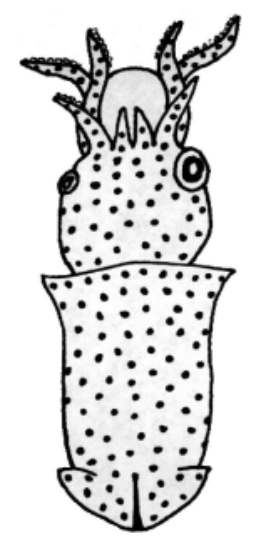

Eye dimorphism

Fig. 3. Sepioteuthis australis. Illustrations of morphological abnormalities observed in field-sampled eggs. (A) Eggs at gastrulation (Stage 12, after Segawa et al. 1988); (B) and (C) are late stage embryos (Stage 29, after Segawa et al. 1988) 


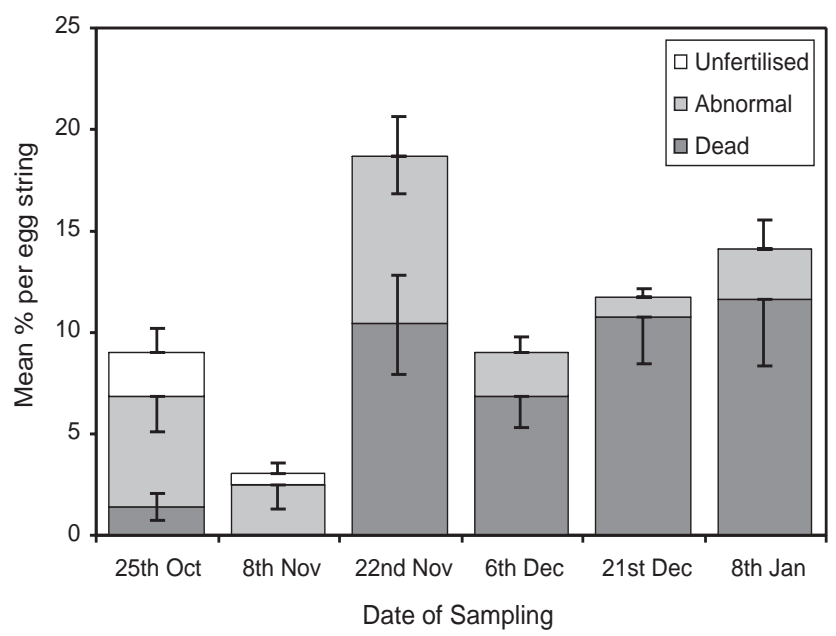

Fig. 4. Sepioteuthis australis. Temporal variation in the percent frequency of developmental error of egg strings. Eggs from a total of 376 egg strings were included in the analyses. Error bars: $\pm \mathrm{SE}$

of the sac from the developing embryo. Mantle deformities, typified by mantle detachment (Fig. 3C), accounted for $13.0 \%$ of abnormalities (Table 1). Abnormalities in eye development, largely characterised by dimorphism (Fig. 3C), accounted for $11.1 \%$ of abnormalities (Table 1). Only $1.9 \%$ of abnormalities related to errors in arm development (Table 1); these were typified by stunting or complete inhibition of arm development (Fig. 3C). Finally, mean incidence of embryonic mortality per strand varied significantly during the spawning season (Kruskal-Wallis: $H_{5}=$ $18.29, \mathrm{p}<0.003)$. Frequency of mortality varied between $1.40 \pm 0.68 \%$ SE eggs per strand in late October and $11.61 \pm 3.23 \%$ SE eggs per strand in early January (Fig. 4). No dead embryos were found during early November.

Incidence of developmental abnormality varied significantly with egg position when measured over the entire spawning season (Fig. 5; Kruskal-Wallis: $\left.H_{8}=30.54, \mathrm{p}<0.001\right)$. Mean percentage abnormality at

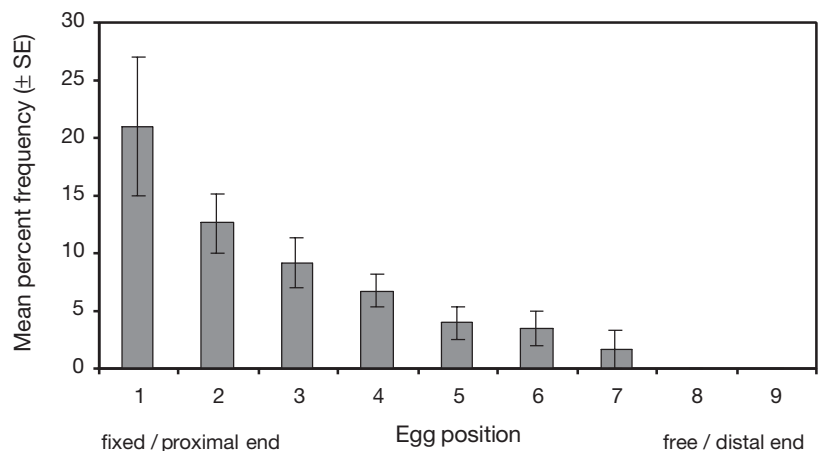

Fig. 5. Sepioteuthis australis. Mean frequency of embryonic abnormality per egg position when measured across the entire sampling period $\left(\mathrm{N}_{\text {strands }}=481, \mathrm{~N}_{\text {eggs }}=2649\right)$

each egg position decreased from $20.94 \%$ at Position 1 (fixed/proximal end) to $1.67 \%$ at Position 7 and $0.00 \%$ at Positions 8 and 9 (free/distal end). The association between frequency of abnormality and egg position strengthened as the spawning season progressed. Egg strands collected in late October and early November were characterised by a relatively even distribution of abnormalities across egg Positions 1 to 7 (Fig. 6). Frequency of abnormality was not associated with egg position during this initial phase of spawning. Correlation between developmental abnormality and egg position was first evident during late November: at this time $64 \%$ of abnormalities were located within egg Positions 1, 2 and 3 (Fig. 6). By early December 49\% of abnormalities were at egg Positions 1 and 2; this decreased to $34 \%$ in late December. Towards the end of the spawning season (early January), $39 \%$ of abnormalities were located at egg Position 1 (Fig. 6).

Inter-site variation in frequency of abnormality was investigated by comparing data from unfouled egg strands collected at Sites A, B, and C during early December. No egg strands contained unfertilised eggs at this time. Mean percentage mortality per strand was not significantly associated with sample site (KruskalWallis: $H_{2}=2.38, \mathrm{p}=0.30$ ). Mean values ranged from

Table 1. Sepioteuthis australis. Frequency of developmental error in field-sampled eggs during a spring/summer spawning season in Great Oyster Bay, Eastern Tasmania, Australia

\begin{tabular}{|c|c|c|c|c|c|c|c|}
\hline $\begin{array}{l}\text { Date } \\
\text { (dd/mm/yy) }\end{array}$ & $\begin{array}{l}\text { No. of eggs } \\
\text { sampled }\end{array}$ & $\begin{array}{l}\text { External yolk } \\
\text { sac deformity }\end{array}$ & $\begin{array}{l}\text { Reduction in } \\
\text { embryo size }\end{array}$ & $\begin{array}{l}\text { Mantle } \\
\text { deformity }\end{array}$ & $\begin{array}{c}\text { Eye } \\
\text { deformity }\end{array}$ & $\begin{array}{c}\text { Arm } \\
\text { deformity }\end{array}$ & $\begin{array}{c}\text { Total no. of } \\
\text { abnormalities }\end{array}$ \\
\hline $25 / 10 / 00$ & 241 & 7 & 2 & 0 & 2 & 1 & 12 \\
\hline 08/11/00 & 133 & 1 & 0 & 1 & 2 & 0 & 4 \\
\hline $22 / 11 / 00$ & 385 & 4 & 9 & 1 & 1 & 0 & 15 \\
\hline $06 / 12 / 00$ & 519 & 9 & 3 & 1 & 0 & 0 & 13 \\
\hline $21 / 12 / 00$ & 502 & 1 & 1 & 3 & 1 & 0 & 6 \\
\hline 08/01/00 & 134 & 3 & 0 & 1 & 0 & 0 & 4 \\
\hline Total & 1914 & 25 & 15 & 7 & 6 & 1 & 54 \\
\hline
\end{tabular}



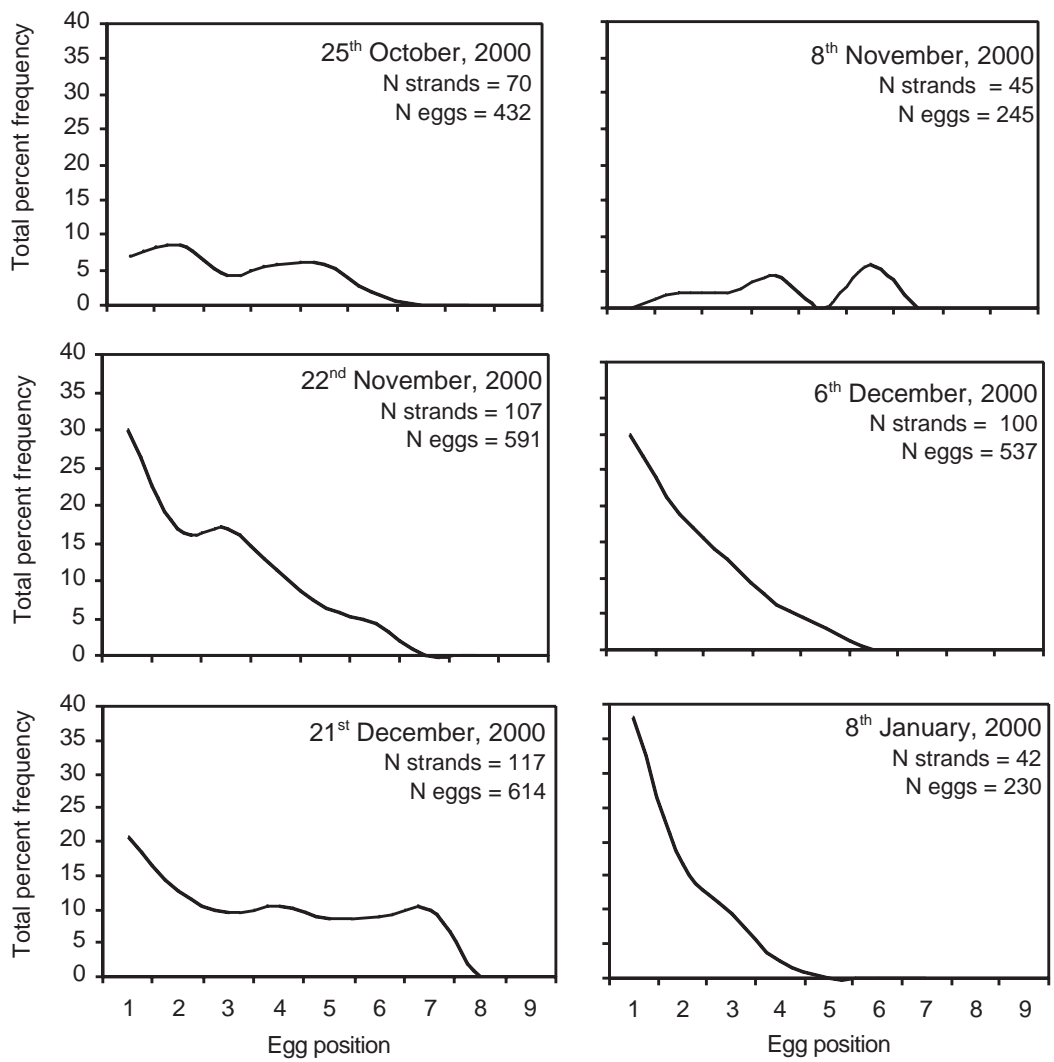

Fig. 6. Sepioteuthis australis. Total frequency of embryonic abnormality per egg position on each sample date $\left(\mathrm{N}_{\text {strands }}=481, \mathrm{~N}_{\text {eggs }}=2649\right)$ strands but accounted for a mean $0.80 \pm$ $0.46 \%$ SE eggs in unfouled egg strands. No significant correlation was found between biofouling and frequency of developmental abnormality: mean values ranged from $3.53 \pm 1.00 \% \mathrm{SE}$ eggs per strand in unfouled strands to $2.04 \pm 0.69 \%$ SE eggs per strand in fouled strands (2 sample $t$-test: $\left.t_{144}=1.20, \mathrm{p}=0.23\right)$. Highly significant correlation was noted between biofouling and incidence of mortality: unfouled egg strands contained a mean $11.31 \pm 2.49 \% \mathrm{SE}$ mortality compared to a mean $2.14 \pm 0.94 \%$ SE in fouled egg strands (2 sample $t$-test: $\left.t_{97}=3.45, \mathrm{p}<0.001\right)$.

Mean daily SBT $\left({ }^{\circ} \mathrm{C}\right)$ increased steadily during the spawning season from $12.9^{\circ} \mathrm{C}$ in late September to $18.9^{\circ} \mathrm{C}$ in midDecember (Table 2). Daily fluctuations in SBT typically measured between 1 and $2{ }^{\circ} \mathrm{C}$. Fluctuations $>2{ }^{\circ} \mathrm{C} \mathrm{d} \mathrm{d}^{-1}$ were most prevalent during early and mid-October and were noted on $24 \%$ of days during this period (Table 2). Hourly changes in $\mathrm{SBT}>0.5$ and $>0.25^{\circ} \mathrm{C}$ were also most common during early and mid-October; these changes occurred $\leq 2$ and $\leq 6$ times per $24 \mathrm{~h}$ respectively (Table 2 ).
$2.96 \pm 1.61 \%$ SE at Site A to $16.1 \pm 13.1 \%$ SE at Site B. In contrast, mean percentage abnormality per strand was strongly correlated with sample site (KruskalWallis: $\left.H_{2}=6.94, \mathrm{p}<0.05\right)$. Mean values ranged from $7.50 \pm 4.79 \%$ SE at Site B to $0.52 \pm 0.52 \%$ SE at Site C. On this basis, Site B was characterised by a comparatively high incidence of abnormally developed embryos at that time.

Biofouled eggs strands were characterised by a comparatively lower incidence of both unfertilised and dead eggs: unfertilised eggs were never found in fouled egg

\section{DISCUSSION}

The results of this study suggest that non-viable eggs and embryos account for $\sim 11 \%$ of eggs per strand in a shallow-spawning Sepioteuthis australis population. The incidence of non-viable eggs and embryos varied significantly during the spawning season and ranged between 3 and $19 \%$ of eggs per strand. Unfertilised eggs were only found during the first month of spawning and occurred at relatively low frequencies $(\leq 2 \%$ eggs per strand). In contrast, egg mortality and devel-

Table 2. Sepioteuthis australis. Temporal changes in sea-bottom temperature $\left(\mathrm{SBT},{ }^{\circ} \mathrm{C}\right)$ during a spring/summer spawning season. Relatively pronounced daily and hourly changes in SBT $\left(>2.0^{\circ} \mathrm{C} \mathrm{d}^{-1}\right.$ and $\left.>0.50^{\circ} \mathrm{C} \mathrm{h}^{-1}\right)$ were most frequent in the 2 wk between 8 and 24 October 2000 (in bold)

\begin{tabular}{|c|c|c|c|c|c|}
\hline $\begin{array}{l}\text { Period } \\
\text { (dd/mm/yy) }\end{array}$ & $\begin{array}{l}\text { Mean daily } \\
\text { SBT }\left({ }^{\circ} \mathrm{C}\right)\end{array}$ & $\begin{array}{l}\text { Daily range in } \\
\mathrm{SBT}>2.0^{\circ} \mathrm{C}(\%)\end{array}$ & $\begin{array}{l}\text { Daily range in } \\
\mathrm{SBT}>1.0^{\circ} \mathrm{C}(\%)\end{array}$ & $\begin{array}{c}\text { No. of } \\
\Delta \mathrm{SBT}>0.50^{\circ} \mathrm{C}\left(\mathrm{h}^{-1}\right)\end{array}$ & $\begin{array}{c}\text { No. of } \\
\Delta \mathrm{SBT}>0.25^{\circ} \mathrm{C}\left(\mathrm{h}^{-1}\right)\end{array}$ \\
\hline $25 / 09 / 00-07 / 10 / 00$ & $12.90 \pm 0.16 \mathrm{SE}$ & 0.0 & 84.6 & 4 (max. 2 per 24 h) & 36 (max. 6 per $24 \mathrm{~h}$ ) \\
\hline 08/10/00 - 24/10/00 & $13.45 \pm 0.16 \mathrm{SE}$ & 23.5 & 47.1 & 6 (max. 2 per 24 h) & 47 (max. 6 per $24 h)$ \\
\hline $25 / 19 / 00-07 / 11 / 00$ & $14.19 \pm 0.17 \mathrm{SE}$ & 0.0 & 71.4 & 2 (max. 1 per 24 h) & 36 (max. 8 per 24 h) \\
\hline $08 / 11 / 00-21 / 11 / 00$ & $15.69 \pm 0.14 \mathrm{SE}$ & 7.1 & 42.9 & 4 (max. 3 per 24 h) & 16 (max. 4 per $24 \mathrm{~h})$ \\
\hline $22 / 11 / 00-05 / 12 / 00$ & $18.06 \pm 0.14 \mathrm{SE}$ & 7.1 & 85.7 & 5 (max. 3 per 24 h) & 46 (max. 7 per $24 \mathrm{~h}$ ) \\
\hline $06 / 12 / 00-20 / 12 / 00$ & $18.93 \pm 0.11 \mathrm{SE}$ & 6.7 & 66.7 & 1 (max. 1 per 24 h) & 31 (max. 7 per $24 \mathrm{~h}$ ) \\
\hline $21 / 12 / 00-07 / 01 / 01$ & $17.70 \pm 0.23 \mathrm{SE}$ & 5.9 & 64.7 & 1 (max. 1 per 24 h) & 31 (max. 4 per $24 \mathrm{~h}$ ) \\
\hline
\end{tabular}


opmental abnormalities were noted throughout the entire season with frequency of mortality approximately double that of abnormality. Defects in external yolk-sac morphology accounted for nearly $50 \%$ of all abnormalities. Illustrated reductions in embryo size and deformities of the mantle, arms and eyes are consistent with developmental abnormalities reported in other squid species (Todarode pacificus: Sakurai et al. 1996; Loligo forbesi: Murray 1999; Loligo vulgaris reynaudii: Oosthuizen et al. 2002a). The intra-season variation in frequency of abnormalities within field-sampled $S$. australis eggs may reflect changes in (1) environmental conditions, (2) egg mass size and/or (3) levels of biological fouling.

Cephalopod development is intrinsically linked to water temperature (e.g. Hamabe 1960, Arnold 1965, Boletzky 1974, 1979). Incubation of eggs at temperatures outside the optimal species range results in increased levels of mortality and abnormality (O'Dor et al. 1982, Sakurai et al. 1996, Gowland et al. 2002, Oosthuizen et al. 2002b). Laboratory rearing of squid eggs indicates that controlled temperature changes should measure $\leq 1^{\circ} \mathrm{C} \mathrm{d}^{-1}$ which equates to $\leq 0.04^{\circ} \mathrm{C} \mathrm{h}^{-1}$ (Hanlon 1990). Experimental rearing of Loligo vulgaris reynaudii indicates that exposure to fluctuating temperatures $\left( \pm 3\right.$ to $\left.9^{\circ} \mathrm{C}\right)$ elevates frequency of developmental abnormality to levels exceeding those associated with eggs maintained at constant temperatures (Oosthuizen et al. 2002b). This study additionally suggests that upward fluctuations in developmental temperature $\left(+4.3^{\circ} \mathrm{C} \mathrm{h}^{-1}\right)$ are comparatively more deleterious than downward fluctuations in developmental temperature $\left(-5.5^{\circ} \mathrm{C} \mathrm{h}^{-1}\right)$. The results of the present study on Sepioteuthis australis indicate a November peak in frequency of developmental abnormality (19\% eggs per strand). This peak may reflect the relatively pronounced fluctuations in SBT $\left(\Delta>2^{\circ} \mathrm{C} \mathrm{d}^{-1}\right)$ measured during the preceding 8 wk of egg development. Adaptation of Segawa's (1987) equation relating temperature and duration of embryonic phase in $S$. lessoniana generates an approximate oviposition date of 9 October for $S$. australis eggs collected on 22 November. As Segawa's equation assumes constant thermal conditions, oviposition date was tentatively estimated on the basis of mean field temperature during the preceding $8 \mathrm{wk}$. This estimate suggests that the $S$. australis eggs characterised by greatest frequency of developmental abnormality were progressing through early developmental stages when temperature fluctuations of $>2^{\circ} \mathrm{C} \mathrm{d}^{-1}$ were most common. Fluctuations $>2^{\circ} \mathrm{C} \mathrm{d}^{-1}$ occurred on $24 \%$ of days between 8 and 24 October, compared to a maximum $7.1 \%$ of days in any other 2 wk period. Experimental rearing of loliginid eggs indicates maximal thermal sensitivity during the early stages of development (S. lessoniana: Segawa 1995;
L.v. reynaudii: Oosthuizen et al. 2002b). This coincidence of heightened embryonic sensitivity and relatively pronounced thermal variation in the field may account for the peak in developmental abnormalities during late November. It should be noted that downward fluctuations in temperature accounted for the majority of fluctuations measured during this period $\left(57 \% \Delta>0.25^{\circ} \mathrm{C} \mathrm{h}^{-1} ; 65 \% \Delta>0.50^{\circ} \mathrm{C} \mathrm{h}^{-1}\right)$.

With the exception of this November peak, frequency of developmental abnormality increased steadily during the final $8 \mathrm{wk}$ of the spring/summer spawning season. Analysis of environmental data suggests that ambient conditions varied in a similar manner during this period, i.e. SBT increased steadily and fluctuations were of comparable magnitude. The progressive increase in incidence of developmental abnormalities must therefore parallel another change in conditions. The relationship between incidence of developmental abnormality and within-strand egg position appeared to strengthen temporally. Developmental abnormalities became increasingly clustered towards the fixed/proximal end of egg strands as the spawning season progressed $_{i}$ this clustering may reflect increased hypoxia within egg masses. Hypoxic conditions have been noted within the centres of amphibian (e.g. Seymour 1995) and molluscan (e.g. Strathmann \& Strathmann 1995) egg masses. Low oxygen conditions are associated with retardation of development and/or egg mortality (e.g. Baker \& Mann 1994, Mills \& Barnhart 1999, Woods 1999). Hypoxia has previously been linked to developmental abnormalities in loliginid squid egg masses held in the laboratory. Arnold (1990) states that the centre of a Loligo spp. egg mass 'tends to become fairly anaerobic' and that development becomes 'retarded or abnormal' if egg strands are not separated out. Loliginid egg-laying behaviour typically involves the deposition of new strands onto the periphery of extant egg masses (McGowan 1954, Arnold 1962). Discrete Sepioteuthis australis egg masses may contain $>600$ egg strands (Moltschaniwskjy \& Pecl 2002) and large mass size is likely to restrict water flow therefore reducing aeration. Whilst developmental abnormalities in $S$. australis eggs were distributed relatively evenly across egg positions during the first month of spawning, $39 \%$ of all abnormalities were located at the most proximal egg position by the end of the season. This progressive clustering may reflect congruent increases in egg mass and hypoxic conditions. Proximal clustering of developmental abnormalities has been observed in field-sampled Loligo forbesi egg strands (Murray 1999). Use of oxygen probes during subsequent field assessments of cephalopod eggs will permit direct testing of the hypoxia hypothesis.

Late stage Sepioteuthis australis eggs strands typically support epiphytic growth. A previous study sug- 
gests that biofouling may be beneficial to egg development in this species, as fouled egg strands display comparatively reduced levels of egg mortality (Steer et al. 2002). Photosynthesis of endogenous algae has been positively associated with development of amphibian eggs (Pinder \& Friet 1994) and molluscan eggs (Cohen \& Strathmann 1996). The results of the present study confirm the existence of a relationship between biofouling and reduced egg mortality in S. australis. A similar relationship is revealed between biofouling and reduced incidence of unfertilised eggs. In apparent contrast, no correlation exists between biofouling and incidence of morphological abnormality. Frequency of abnormality did not differ significantly between fouled and unfouled egg strands. If biofouling conferred significant benefit during egg development in $S$. australis, a continuum of effect might be expected, i.e. suppression of abnormality levels in tandem with suppression of mortality levels. As no such continuum was identified during the present study, an alternative explanation is necessary. Reversal of cause and effect offers one possibility, i.e. good quality $S$. australis eggs may support epiphytic growth rather than epiphytic growth ensuring good quality $S$. australis eggs. If epiphytic colonisation occurs exclusively upon capsules containing live fertilised eggs, the relationship between biofouling and reduced egg mortality may be entirely incidental. By this rationale, correlation may simply reflect an absence of epiphytic growth on dead or unfertile egg capsules and not a positive relationship between egg development and biofouling. Comparable levels of morphological abnormality in fouled and unfouled egg strands provide support for this hypothesis. Indeed, cephalopod culture experiments suggest 'unsatisfactory hatching due to the attachment of great quantities of diatoms or green algae' (Choe 1966). Further investigation is required to clarify the relationship between development and epiphytic colonisation of $S$. australis eggs.

This study provides in situ assessment of development in a commercially important cephalopod population. Rates of embryonic abnormality ( 11\%) are comparable with laboratory rates reported for other loliginids reared under natural thermal conditions: 5 to $10 \%$ in Loligo vulgaris reynaudii (Oosthuizen et al. 2002 b) and 7 to $8 \%$ in L. forbesi (Gowland et al. 2002). The results of the present study suggest that rates of embryonic abnormality primarily reflect environmental conditions and consequently vary with spawning date and site. Rates may additionally reflect the quality of yolk provision. For example, deficiencies in dietary phospholipids can induce developmental abnormalities in cultured fish larvae (e.g. Kanazawa et al. 1981, Geurden et al. 1995). Irrespective of cause, quantification of embryonic abnormality within natural popula- tions may generate valuable information on environmental conditions and population dynamics. A previous study of embryogenesis in sea urchins concludes that quantification of embryonic abnormalities has potential as a 'rapid and sensitive model bioassay' for monitoring marine pollution (Lytechinus variegatus; Bottger \& McClintock 2001). In situ investigation of embryonic development in amphipods suggests that rates of abnormality are more toxicant-sensitive than measures of fecundity, reproductive success or developmental stage (Sundelin \& Erikkson 1998). Assessment of embryonic abnormality in coastal spawning cephalopods may provide an indirect measure of environmental quality, and additionally, assessment of embryonic success in commercially exploited cephalopod populations may assist in fisheries management.

Acknowledgements. Thanks to G. Pecl, S. Wilcox and S. Talbot for their help with field work. F.C.G. was supported by a studentship from the Biotechnology and Biological Sciences Research Council and by a travel grant from The British Society of Developmental Biology. M.A.S. was supported by a University of Tasmania Postgraduate Scholarship. This work was supported by a Fisheries Research Development Corporation grant (2000/121) awarded to N.A.M.

\section{LITERATURE CITED}

Adams NL, Shick JM (2001) Mycosporine-like amino acids prevent UVB-induced abnormalities during early development of the green sea urchin Strongylocentrotus droebachiensis. Mar Biol 138(2):267-280

Arnold JM (1962) Mating behaviour and social structure in Loligo pealei. Biol Bull (Woods Hole) 123:53-57

Arnold JM (1965) Normal embryonic stages of the squid Loligo pealei (Lesueur). Biol Bull (Woods Hole) 128:24-32

Arnold JM (1990) Embryonic development of the squid. In: Gilbert DL, Adelman WJ Jr, Arnold JM (eds) Squid as experimental animals. Plenum Press, New York, p 77-90

Baker SM, Mann R (1994) Description of metamorphic phases in the oyster Crassostrea virginica and effects of hypoxia on metamorphosis. Mar Ecol Prog Ser 104:91-99

Ban SH, Lee HW, Shinada A, Toda T (2000) In situ egg production and hatching success of the marine copepod Pseudocalanus newmani in Funka Bay and adjacent waters off southwestern Hokkaido, Japan: associated to diatom bloom. J Plankton Res 22(5):907-922

Biggs J, Epel D (1991) Egg capsule sheath of Loligo opalescens Berry: structure and association with bacteria. J Expt Zool 259:263-267

Boletzky Sv (1974) The 'larvae' of cephalopoda: a review. Thalassia Jugosl 10:45-76

Boletzky Sv (1979) Observations on the early post-embryonic development of Loligo vulgaris (Mollusca: Cephalopoda). Rap Comm Int Mer Medit 25/26 (10):155-158

Boletzky Sv (1989) Recent studies on spawning, embryonic development, and hatching in the Cephalopoda. Adv Mar Biol 25:85-115

Bottger SA, McClintock JB (2001) The effects of organic and inorganic phosphates on fertilization and early development in the sea urchin Lytechinus variegatus (Echino- 
dermata: Echinoidea). Comp Biochem Physiol C 129(4): 307-315

Chen CP, Chen BY (1992) Effects of high temperature on larval development and metamorphosis of Arachnoides placenta (Echinodermata, Echinoidea). Mar Biol 112(3): 445-449

Choe S (1966) On the eggs, rearing habits of the fry, and growth of some cephalopoda. Bull Mar Sci 16:330-348

Cohen CS, Strathmann RR (1996) Embryos on the edge of tolerance: effects of environment and structure of egg masses on supply of oxygen to embryos. Am Zool 39(2): 253-260

Geurden I, Charlon N, Marion D, Bergot P (1995) Dietary phospholipids and body deformities in carp Cyprinus carpio L. larvae. In: Lavens P, Jaspers E, Roelants I (eds) Larvi'95-Fish and Shellfish Symposium, Gent, Belgium. Euro Aquacult Soc Spec Publ 24:162-165

Gonçalves F, Ribeiro R, Soares AMVM (1995) Laboratory study of effects of temperature and salinity on survival and larval development of a population of Rhithropanopeus harrisii from the Mondego river estuary, Portugal. Mar Biol 121(4):639-645

Gowland FC, Boyle PR, Noble LR (2002) Morphological variation provides a method of estimating thermal niche in hatchlings of the squid Loligo forbesi (Mollusca; Cephalopoda). J Zool (in press)

Graham M, Hop H (1995) Aspects of reproduction and larval biology of Arctic cod (Boreogadus saida). Arctic 48(2) $130-135$

Hamabe M (1960) Observations of early development of a squid Loligo bleekeri Keferstein. Ann Rep Jpn Sea Reg Fish Res Lab 6:149-155

Hanlon RT (1990) Maintenance, rearing and culture of teuthoid and sepioid squids. Plenum Press, New York

Johnson LJ, Mill PJ, Hull SL, Ducrotoy JP (2000) The occurrence of abnormal embryos in two ovoviviparous barnacle-dwelling littorinids. J Mar Biol Assoc UK 80(3): $547-548$

Kanazawa A, Teshima S, Inamori S, Iwashita T, Nagao A (1981) Effects of phospholipids on growth, survival rate and incidence of malformation in the larval ayu. Mem Fac Fish Kagoshima Univ 30:301-309

Marthy HJ (1969) Aufzucht von Embryonen und Embryonalfragmenten, ausserhalb des Chorions, von Loligo vulgaris L., mit speziellen Bemerkungen zum Auftreten von Manteldeformationen. Ann Embryol Morphog 3:3-19

Maxwell MR, Hanlon RT (2000) Female reproductive output in the squid Loligo pealei: multiple egg clutches and implications for spawning strategy. Mar Ecol Prog Ser 199: $159-170$

Maxwell MR, Macy MK, Odate S, Hanlon RT (1998) Evidence of multiple spawning by squids (Loligo pealei) in captivity. Biol Bull (Woods Hole) 195:225-226

McGowan JA (1954) Observations on the sexual behaviour and spawning of the squid Loligo opalescens at La Jolla, California. Calif Fish Game 40:47-54

Melo YC, Sauer WHH (1999) Confirmation of serial spawning in the chokka squid Loligo vulgaris reynaudii off the coast of South Africa. Mar Biol 135:307-313

Mills NE, Barnhart MC (1999) Effects of hypoxia on embryonic development in two Ambystoma and two Rana species. Physiol Biochem Zool 72(2):179-188

Murray FC (1999) Developmental abnormalities in the cephalopod embryo. BsC hons thesis, University of Aberdeen

Naef A (1928) Die Cephalopoden, Monograph. Fauna Flora del Golfo di Napoli 35, Friedländer \& Son, Berlin

O'Dor RK, Balch N, Foy EA, Hirtle RWM, Johnston DA, Ama-

Editorial responsibility: John Lawrence (Contributing Editor),

Tampa, Florida, USA ratunga T (1982) Embryonic development of the squid, Illex illecebrosus, and fefect of temperature on development rates. J Northwest Atl Fish Sci 3:41-45

Oosthuizen A, Roberts M, Sauer W (2002a) Early post-cleavage stages and abnormalities identified in the embryonic development of chokka squid eggs (Loligo vulgaris reynaudii). S Afr J Mar Sci (in press)

Oosthuizen A, Roberts M, Sauer W (2002b) Temperature effects on the embryonic development and hatching success of the squid Loligo vulgaris reynaudii. Bull Mar Sci (in press)

Pecl G (2000) Comparative life history of tropical and temperate Sepioteuthis squid in Australian waters. PhD thesis, School of Marine Biology and Aquaculture, James Cook University, Townsville

Pecl G (2001) Flexible reproductive strategies in tropical and temperate Sepioteuthis squids. Mar Biol 138:93-101

Pinder AW, Friet SC (1994) Oxygen transport in egg masses of the amphibians Rana sylvatica and Ambrystoma maculatum-convection, diffusion and oxygen production by algae. J Exp Biol 197:17-30

Ranzi S (1929) Suscettibilita differenziale nello sviluppo dei Cefalopodi. Pubbl Staz Zool Nap 9:81-160

Rocha F, Guerra A (1996) Signs of extended and intermittent terminal spawning in the squids Loligo vulgaris Lamarck, and Loligo forbesi Steenstrup (Cephalopoda: Loliginidae). J Exp Mar Biol Ecol 207:177-189

Rodhouse PG (2001) Managing and forecasting squid fisheries in variable environments. Fish Res 54:3-8

Sakurai Y, Bower JR, Nakamura Y, Yamamoto S, Watanabe K (1996) Effect of temperature on development and survival of Todarodes pacificus embryos and paralarvae. Am Malacol Bull 13(1/2):89-95

Sauer WHH, McCarthy C, Smale MJ, Koorts AS (1993) An investigation of the egg distribution of the chokka squid, Loligo vulgaris reynaudii, in Krom Bay, South Africa. Bull Mar Sci 53:1066-1077

Segawa S (1987) Life history of the oval squid, Sepioteuthis lessoniana in Kominato and adjacent waters Central Honshu, Japan. J Tokyo Univ Fish 74:67-105

Segawa S (1995) Effect of temperature on oxygen consumption of juvenile oval squid Sepioteuthis lessoniana. Fish Sci 61(5):743-746

Segawa S, Yang WT, Marthy HJ, Hanlon RT (1988) Illustrated embryonic stages of the eastern Atlantic squid Loligo forbesi. Veliger 30(3):230-243

Seymour RS (1995) Oxygen uptake by embryos in gelatinous egg masses of Rana sylvatica: the roles of diffusion and convection. Copeia 18:626-635

Sokolova IM (1995) Embryonic abnormalities in populations of Littorina saxatilis (Olivi) (Gastropoda, Prosobranchia) in the White Sea. J Molluscan Stud 61:303-311

Steer MA, Moltschaniwskyj NA, Gowland FC (2002) Temporal variability in embryonic development and mortality in the temperate oval squid Sepioteuthis australis: a field assessment (in press)

Strathmann RR, Strathmann MF (1995) Oxygen supply and limits on aggregation of embryos. J Mar Biol Assoc UK 75(2):413-428

Sundelin B, Eriksson AK (1998) Malformations in embryos of the deposit-feeding amphipod Monoporeia affinis in the Baltic Sea. Mar Ecol Prog Ser 171:165-180

Wang LH, Tsai CL (2000) Effects of temperature on the deformity and sex differentiation of tilapia, Oreochromis mossambicus. J Exp Zool 286(5):534-537

Woods HA (1999) Egg-mass size and cell size: effects of temperature on oxygen distribution. Am Zool 39(2):244-252

Submitted: May 15, 2002; Accepted: June 29, 2002

Proofs received from author(s): October 28, 2002 